\title{
Synthesis, Characterization and Biological Application of Adducts of Bis(S-ethyltrithiocarbonato)nickel(II) with Heterocyclic Amines
}

\author{
GURPREET KOUR, INDERJEET KOUR, POOJA SHARMA and RENU SACHAR.
}

Department of Chemistry, University of Jammu, Babasaheb Ambedkar Road, Jammu-180006, India

gurpreetkour94@yahoo.com

Received 30 April 2014 / Accepted 16 May 2014

\begin{abstract}
Eleven new adducts of bis(S-ethyltrithiocarbonato)nickel(II) with heterocyclic amines have been described. Structural features of adducts isolated in the solid state are established by several techniques using elemental analysis, molar conductance, magnetic measurements, TGA-DTA and spectroscopic studies which include FTIR, UV-Vis, mass. These studies suggest that adducts have the general formula $\left[\mathrm{Ni}\left(\mathrm{S}_{2} \mathrm{CSC}_{2} \mathrm{H}_{5}\right)_{2} \mathrm{~L}_{2}\right]$ where $\mathrm{L}=$ cyano-, amino-, chloro-, ethylpyridine. Antifungal activities of these adducts have been carried out against the fungal strain Sclerotium rolfsii and Fusarium oxysporium and some of these adducts showed noticeable activity against the fungus. Various studies support the distorted octahedral geometry around $\mathrm{Ni}(\mathrm{II})$ ion.
\end{abstract}

Keywords: Bis(S-ethyltrithiocarbonato)nickel(II), Heterocyclic amines, Antifungal studies

\section{Introduction}

1,1-Dithiolates form an interesting family of sulfur donor ligands. They have been extensively used in classical and organometallic chemistry for several years ${ }^{1-3}$. Among these much work has been done on alkyl dithiacarbamates, dithiocarboxylates, dithiocarbonates but little attention has been paid to alkyl trithiocarbonates ${ }^{4-10}$. Trithiocarbonates are used as antioxidant additives to lubricate oil and greases ${ }^{11}$, against human tumor ${ }^{12}$. Trithiocarbonate complexes have received attention because of the dual nature of metal $-\mathrm{CS}_{3}$ moiety as an electrophilic and nucleophilic reagents, which makes them versatile intermediates for the synthesis of other oil thio species. Although the main application is the treatment of a variety of rheumatic diseases, some of these compounds have shown to have antileshmanial activity in vitro inhibitory effect on HIV or activity tumor cell ${ }^{13-14}$. Organotrithiocarbonates have found many applications in various fields such as in analysis, organic synthesis, medicine, industry and agriculture some of these applications are as flotation agents, vulcanization accelerators, pesticides, plant defoliants, rust inhibitor, lubricant oil additives, and some have recently reported to possess activity as antiradiation drugs ${ }^{15-16}$. S-alkyltrithiocarbonates commonly known as thioxanthates coordinate with a number of transition metals to form stable complexes. In order to investigate the ability of these stable complexes to extend their coordination sphere, here in this paper we 
report the synthesis and characterization of a new series of adducts of bis(Sethyltrithiocarbonato)nickel(II) with various nitrogen donors.

\section{Experimental}

The sodium salt of $S$-ethyltrithiocarbonate was prepared (as reported in literature) ${ }^{17}$ by the drop wise addition of the ethanethiol $(1 \mathrm{~mol})$ to a saturated solution of sodium hydroxide at $0{ }^{\circ} \mathrm{C}$, followed by the addition of excess carbon disulfide $(1.2 \mathrm{~mol})$. The yellow precipitate formed immediately was collected by filteration and twice recrystallized from water-acetone mixture. The salt was characterized by its unpleasant odour and was stored in vacuum desiccators over phosphorus pentoxide.

$$
\mathrm{C}_{2} \mathrm{H}_{5} \mathrm{SH}+\mathrm{CS}_{2}+\mathrm{NaOH} \stackrel{0^{\circ} \mathrm{C}}{\longrightarrow} \mathrm{C}_{2} \mathrm{H}_{5} \mathrm{SCS}_{2} \mathrm{Na}^{+}+\mathrm{H}_{2} \mathrm{O}
$$

\section{Synthesis of complex bis(S-ethyltrithiocarbonato)nickel(II)}

To the sodium salt of $S$-ethyltrithiocarbonate $(0.02 \mathrm{~mol})$ an aqueous solution of $\mathrm{NiCl}_{2} 6 \mathrm{H}_{2} \mathrm{O}$ $(0.01 \mathrm{~mol})$ was added. The mixture was immediately extracted with several portions of ether and the combined extracts were dried over anhydrous magnesium sulfate. The ether was removed under reduced pressure and shiny black crystals were isolated. The composition of the complex was established to be $\left[\mathrm{Ni}\left(\mathrm{S}_{2} \mathrm{CSC}_{2} \mathrm{H}_{5}\right)_{2}\right]$ by the elemental analysis.

$$
\mathrm{NiCl}_{2} 2 \mathrm{H}_{2} \mathrm{O}+\mathrm{C}_{2} \mathrm{H}_{5} \mathrm{SCS}_{2} \mathrm{Na} \longrightarrow\left[\mathrm{Ni}\left(\mathrm{S}_{2} \mathrm{CSC}_{2} \mathrm{H}_{5}\right)_{2}\right]+2 \mathrm{NaCl}
$$

\section{Synthesis of adducts of bis(S-ethyltrithiocarbonato)nickel(II) with nitrogen donors}

Bis(S-ethyltrithiocarbonato)nickel(II) (0.0026 mol) was dissolved in chloroform (60-80 mL) and stirred for about 10-20 minutes. To the resulting solution, nitrogen donor ligand $(0.0052 \mathrm{~mol})$ was added. The mixture was stirred for two to three days and kept overnight. Blackish green coloured precipitates were formed. The product so obtained was filtered and dried in vacuum desiccator over anhydrous calcium chloride. The composition of the adduct was established to be $\mathrm{Ni}\left[\left(\mathrm{S}_{2} \mathrm{CSC}_{2} \mathrm{H}_{5}\right)_{2} \mathrm{~L}_{2}\right]$ as confirmed by analytical data (Table 1) where $\mathrm{L}=2-$, 3-, 4-ethylpyridine, 2-, 3-chloropyridine, 2-, 3-, 4-cyanopyridine, 2-, 3-, 4-aminopyridine.

$$
\left[\mathrm{Ni}\left(\mathrm{S}_{2} \mathrm{CSC}_{2} \mathrm{H}_{5}\right)_{2}\right]+\mathrm{C}_{5} \mathrm{H}_{5} \mathrm{NX} \longrightarrow\left[\mathrm{Ni}\left(\mathrm{S}_{2} \mathrm{CSC}_{2} \mathrm{H}_{5}\right)_{2}\left(\mathrm{C}_{5} \mathrm{H}_{5} \mathrm{NX}\right)_{2}\right]
$$

Where $\mathrm{X}=\mathrm{CN}, \mathrm{Cl}, \mathrm{C}_{2} \mathrm{H}_{5}, \mathrm{NH}_{2}$

\section{Results and Discussion}

The adducts isolated are green to blackish green in colour. Molar conductance of the adducts suggest their non-electrolytic nature ${ }^{18}$. All the adducts are paramagnetic as suggested by their magnetic moments ${ }^{19}$ (Table 2).

\section{IR spectra}

The IR spectra of the free ligand and the complexes were obtained in the range of 4000-300 $\mathrm{cm}^{-1}$. All the bands present in the IR spectra of the free ligand were also observed in the spectra of the complexes. In the present work IR spectra of the adducts of bis( $S$-ethyltrithiocarbonato)nickel(II) show characteristic bands corresponding to $v(\mathrm{C}-\mathrm{S}-\mathrm{C})_{\text {asym }}$ and $v(\mathrm{C}-\mathrm{S}-\mathrm{C})_{\text {sym }}$ vibrations in the range of $650-710 \mathrm{~cm}^{-1}$. An intense band corresponding to $v(\mathrm{C}-\mathrm{S})$ vibration is also observed for all the adducts synthesized which suggests that thioxanthate is binding as symmetrical bidentate chelating ligand ${ }^{20-21}$. On formation of adducts, there is a shift in the stretching frequencies, because of donation of electrons by the Lewis bases which weakens the metal sulfur bond that leads to corresponding weakening of C-S bond. Moreover it has been observed that the shift of frequency is much more pronounced in case of electron rich bases as compared to electron poor bases. Some of the important bands are given in Table 3. 
Table 1. Analytical data of the adducts

\begin{tabular}{llllllllll}
\hline \multirow{2}{*}{ Compound } & \multicolumn{3}{c}{ Percentage calculated } & \multicolumn{5}{c}{ Percentage Found } \\
\cline { 2 - 9 } & $\mathrm{C}$ & $\mathrm{H}$ & $\mathrm{N}$ & $\mathrm{S}$ & $\mathrm{C}$ & $\mathrm{H}$ & $\mathrm{N}$ & $\mathrm{S}$ \\
\hline 1 & $\begin{array}{l}\text { Bis(S-ethyltrithiocarbonato)bis } \\
\text { (2-ethylpyridine)nickel(II) }\end{array}$ & 35.45 & 4.35 & 3.18 & 43.64 & 34.86 & 3.85 & 2.76 & 41.98 \\
2 & $\begin{array}{l}\text { Bis(S-ethyltrithiocarbonato) bis } \\
\text { (3-ethylpyridine)nickel(II) }\end{array}$ & 35.45 & 4.35 & 3.18 & 43.64 & 33.98 & 4.12 & 3.08 & 42.37 \\
3 & $\begin{array}{l}\text { Bis(S-ethyltrithiocarbonato)bis } \\
\text { (4-ethylpyridine)nickel(II) }\end{array}$ & 35.45 & 4.35 & 3.18 & 43.64 & 34.27 & 4.22 & 3.00 & 41.95 \\
4 & $\begin{array}{l}\text { Bis(S-ethyltrithiocarbonato) bis } \\
\text { (2-chloropyridine)nickel(II) }\end{array}$ & 29.24 & 3.13 & 3.10 & 42.52 & 28.78 & 2.96 & 2.74 & 40.89 \\
5 & $\begin{array}{l}\text { Bis(S-ethyltrithiocarbonato)bis } \\
\text { (3-chloropyridine)nickel(II) }\end{array}$ & 29.24 & 3.13 & 3.10 & 42.52 & 27.74 & 2.88 & 2.82 & 41.22 \\
6 & $\begin{array}{l}\text { Bis(S-ethyltrithiocarbonato)bis } \\
\text { (2-cyanopyridine)nickel(II) }\end{array}$ & 32.95 & 3.22 & 6.40 & 43.94 & 31.87 & 3.18 & 5.83 & 42.64 \\
7 & $\begin{array}{l}\text { Bis(S-ethyltrithiocarbonato)bis } \\
\text { (3-cyanopyridine)nickel(II) }\end{array}$ & 32.95 & 3.22 & 6.40 & 43.94 & 30.91 & 3.09 & 6.03 & 43.78 \\
8 & $\begin{array}{l}\text { Bis(S-ethyltrithiocarbonato)bis } \\
\text { (4-cyanopyridine)nickel(II) }\end{array}$ & 32.95 & 3.22 & 6.40 & 43.94 & 32.09 & 2.98 & 5.94 & 42.15 \\
9 & $\begin{array}{l}\text { Bis(S-ethyltrithiocarbonato)bis } \\
\text { (2-aminopyridine)nickel(II) }\end{array}$ & 30.91 & 3.77 & 6.55 & 44.96 & 28.78 & 3.23 & 6.12 & 42.87 \\
1 & $\begin{array}{l}\text { Bis(S-ethyltrithiocarbonato)bis } \\
\text { (3-aminopyridine)nickel(II) }\end{array}$ & 30.91 & 3.77 & 6.55 & 44.96 & 29.13 & 3.44 & 6.23 & 43.00 \\
1 & $\begin{array}{l}\text { Bis(S-ethyltrithiocarbonato)bis } \\
\text { (4-aminopyridine)nickel(II) }\end{array}$ & 30.91 & 3.77 & 6.55 & 44.96 & 29.22 & 3.48 & 6.43 & 43.12 \\
\hline
\end{tabular}

Table 2. Melting point, Magnetic moment and Molar Conductance of the isolated adducts

\begin{tabular}{|c|c|c|c|c|}
\hline & Compound name & $\begin{array}{l}\text { Melting } \\
\text { point in }{ }^{\circ} \mathrm{C}\end{array}$ & $\begin{array}{l}\text { Magnetic } \\
\text { moment in }\end{array}$ & $\begin{array}{c}\text { Molar } \\
\text { conductance in }\end{array}$ \\
\hline 1 & $\begin{array}{l}\text { Bis(S-ethyltrithiocarbonato)bis(2- } \\
\text { ethylpyridine)nickel(II) }\end{array}$ & 82 & 2.98 & 50.45 \\
\hline 2 & $\begin{array}{l}\text { Bis(S-ethyltrithiocarbonato) bis(3- } \\
\text { ethylpyridine)nickel(II) }\end{array}$ & 88 & 3.21 & 46.28 \\
\hline 3 & $\begin{array}{l}\text { Bis(S-ethyltrithiocarbonato)bis (4- } \\
\text { ethylpyridine)nickel(II) }\end{array}$ & 87 & 3.45 & 52.18 \\
\hline 4 & $\begin{array}{l}\text { Bis(S-ethyltrithiocarbonato)bis(2- } \\
\text { chloropyridine)nickel(II) }\end{array}$ & 78 & 2.91 & 56.98 \\
\hline 5 & $\begin{array}{l}\text { Bis(S-ethyltrithiocarbonato)bis(3- } \\
\text { chloropyridine)nickel(II) }\end{array}$ & 75 & 3.22 & 60.12 \\
\hline 6 & $\begin{array}{l}\text { Bis(S-ethyltrithiocarbonato)bis(2- } \\
\text { cyanopyridine)nickel(II) }\end{array}$ & 83 & 3.34 & 58.87 \\
\hline 7 & $\begin{array}{l}\text { Bis(S-ethyltrithiocarbonato)bis(3- } \\
\text { cyanopyridine)nickel(II) }\end{array}$ & 87 & 3,16 & 49.90 \\
\hline 8 & $\begin{array}{l}\text { Bis(S-ethyltrithiocarbonatobis (4- } \\
\text { cyanopyridine)nickel(II) }\end{array}$ & 86 & 3.02 & 47.76 \\
\hline 9 & $\begin{array}{l}\text { Bis(S-ethyltrithiocarbonato)bis(2- } \\
\text { aminopyridine)nickel(II) }\end{array}$ & 81 & 2.98 & 60.12 \\
\hline 10 & $\begin{array}{l}\text { Bis(S-ethyltrithiocarbonato)bis(3- } \\
\text { aminopyridine)nickel(II) }\end{array}$ & 84 & 3.02 & 48.88 \\
\hline 12 & $\begin{array}{l}\text { Bis(S-ethyltrithiocarbonato)bis(4- } \\
\text { aminopyridine)nickel(II) }\end{array}$ & 86 & 3.13 & 45.56 \\
\hline 13 & $\begin{array}{l}\text { Bis(S-ethyltrithiocarbonato)bis(2- } \\
\text { ethylpyridine)nickel(II) }\end{array}$ & 82 & 2.98 & 50.45 \\
\hline
\end{tabular}


Table 3. Electronic and Vibrational Spectral data of the adducts

\begin{tabular}{clcccccc}
\hline & \multicolumn{6}{c}{ Compound name } & \multicolumn{5}{c}{ Electronic spectra data Vibrational spectral data } \\
\hline 1 & $\begin{array}{l}\text { C-S (C-S-C) } \\
\text { Bis(S-ethyltrithiocarbonato)bis(2- } \\
\text { ethylpyridine)nickel(II) }\end{array}$ & 1032 & 698 & 659 & 13735 & 19000 & 23476 \\
2 & $\begin{array}{l}\text { Bis(S-ethyltrithiocarbonato)bis(3- } \\
\text { ethylpyridine)nickel(II) }\end{array}$ & 1031 & 704 & 660 & 12578 & 18200 & 24536 \\
3 & $\begin{array}{l}\text { Bis(S-ethyltrithiocarbonato)bis(4- } \\
\text { ethylpyridine)nickel(II) }\end{array}$ & 1044 & 688 & 652 & 10883 & 19987 & 24520 \\
4 & $\begin{array}{l}\text { Bis(S-ethyltrithiocarbonato)bis(2- } \\
\text { chloropyridine)nickel(II) }\end{array}$ & 1033 & 692 & 658 & 13500 & 18870 & 26450 \\
5 & $\begin{array}{l}\text { Bis(S-ethyltrithiocarbonato)bis(3- } \\
\text { chloropyridine)nickel(II) }\end{array}$ & 1031 & 700 & 662 & 13654 & 18765 & 25800 \\
6 & $\begin{array}{l}\text { Bis(S-ethyltrithiocarbonato)bis(2- } \\
\text { cyanopyridine)nickel(II) }\end{array}$ & 1030 & 702 & 655 & 13780 & 18989 & 24900 \\
7 & $\begin{array}{l}\text { Bis(S-ethyltrithiocarbonato)bis(3- } \\
\text { cyanopyridine)nickel(II) }\end{array}$ & 1043 & 687 & 651 & 12788 & 20050 & 24978 \\
8 & $\begin{array}{l}\text { Bis(S-ethyltrithiocarbonato)bis(4- } \\
\text { cyanopyridine)nickel(II) }\end{array}$ & 1042 & 693 & 656 & 13314 & 19700 & 26340 \\
9 & $\begin{array}{l}\text { Bis(S-ethyltrithiocarbonato)bis(2- } \\
\text { aminopyridine)nickel(II) }\end{array}$ & 1048 & 694 & 662 & 13453 & 19239 & 24300 \\
10 & $\begin{array}{l}\text { Bis(S-ethyltrithiocarbonato)bis(3- } \\
\text { aminopyridine)nickel(II) }\end{array}$ & 1044 & 701 & 669 & 12546 & 18670 & 24563 \\
11 & $\begin{array}{l}\text { Bis(S-ethyltrithiocarbonato)bis(4- } \\
\text { aminopyridine)nickel(II) }\end{array}$ & 1040 & 708 & 660 & 13800 & 19830 & 25348 \\
\hline
\end{tabular}

\section{UV-Visible spectra}

The electronic spectra of adducts of bis(S-ethyltrithiocarbonato)nickel(II) show three absorption bands in the range of $12500-13800 \mathrm{~cm}^{-1}, 18500-20000 \mathrm{~cm}^{-1}$ and $23000-25000 \mathrm{~cm}^{-1}$. These three bands may be assigned to three spin allowed transitions: ${ }^{3} \mathrm{~A}_{2} \mathrm{~g} \rightarrow{ }^{3} \mathrm{~T}_{2} \mathrm{~g}\left(v^{1}\right)$, ${ }^{3} \mathrm{~A}_{2} \mathrm{~g} \rightarrow{ }^{3} \mathrm{~T}_{1} \mathrm{~g}\left(v^{2}\right)$ and ${ }^{3} \mathrm{~A}_{2} \mathrm{~g} \rightarrow{ }^{-3} \mathrm{~T}_{1} \mathrm{~g}(\mathrm{P})\left(v^{3}\right)$ respectively ${ }^{22}$. The appearance of these bands along with shoulders suggest that the adducts synthesized have distorted octahedral geometry around $\mathrm{Ni}(\mathrm{II})$ metal ion (Table 3).

\section{Thermal studies}

The thermal behavior of one of the representing complex $\mathrm{Ni}\left[\left(\mathrm{S}_{2} \mathrm{CSC}_{2} \mathrm{H}_{5}\right)_{2}\left(\mathrm{C}_{6} \mathrm{H}_{4} \mathrm{~N}_{2}\right)_{2}\right]$ was studied under inert atmosphere in the range of $200-900{ }^{\circ} \mathrm{C}$ and is shown in Figure 1 and it displays weight loss in three steps with different time intervals at different temperatures. These losses indicate decomposition and evaporation of the volatile part of the sample. The curved portion indicates the weight loss during the process of heating. TGA curve of the addition complex bis( $S$ ethyltrithiocarbonato)(3-chloropyridine) nickel(II) shows an initial weight loss of 59.6\% at 157.7 ${ }^{\circ} \mathrm{C}$ which can be correlated with the loss of two molecules of chloropyridine (Calculated $=58.5 \%$ ). At a temperature of $517{ }^{\circ} \mathrm{C}$ both the coordinated thioxanthate molecules are lost (observed wt.loss $=86.2 \%$; Calculated $=88 \%$ ) and a stable sulfide, $\mathrm{NiS}$ is obtained as an end product ${ }^{23}$.

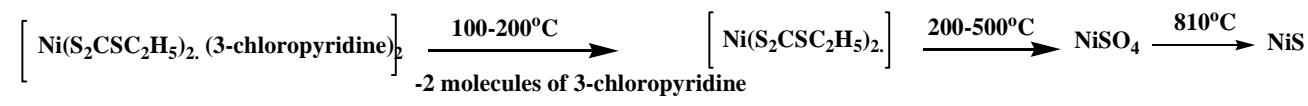




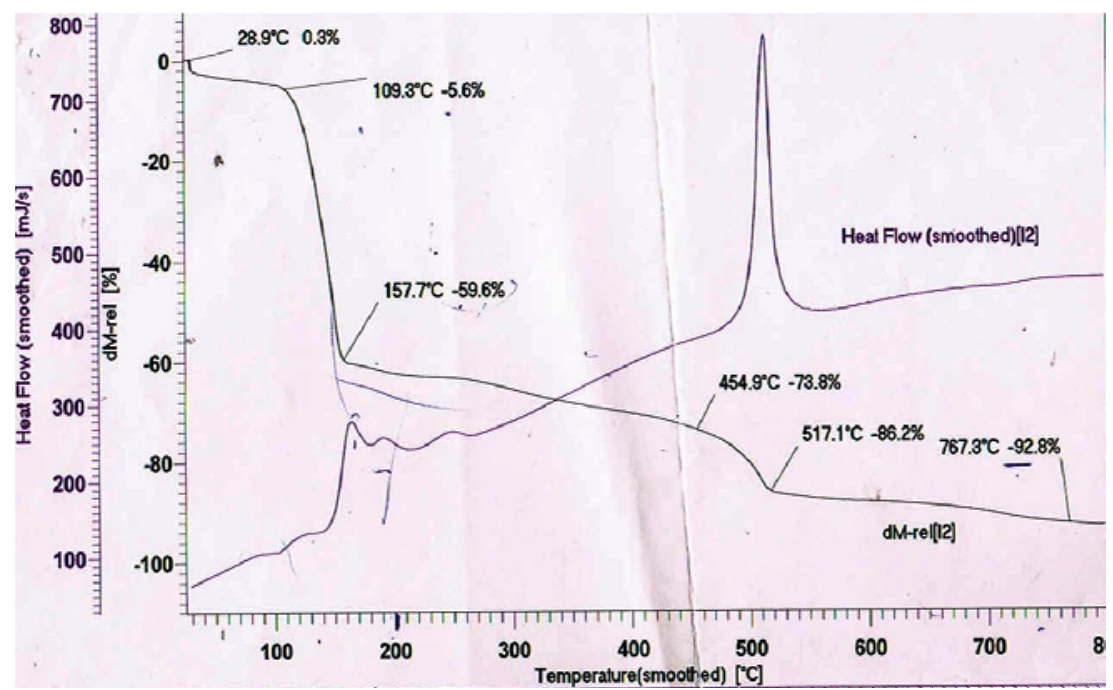

Figure 1. TGA-DTA curve of bis(S-ethyltrithiocarbonato)bis(3-chloropyridine) nickel(II)

\section{Mass spectroscopy}

Mass spectroscopy is one of the most important methods to determine molecular weight of the complexes and to identify the fragments formed during bombardment, which reveal composition and properties of the particular moiety of the complexes ${ }^{24-25}$. Mass spectra of one of these adducts, bis(S-ethyltrithiocarbonato)bis(4-cyanopyridine)nickel(II) has been recorded. The possible formulae of the fragments and their $\mathrm{m} / \mathrm{z}$ ratios are shown in Table 4 . Two important peaks were observed in the mass spectrum: the molecular ion peak, indicating the molecular mass of the complex, which is very weak in case of the complexes investigated and the base peak, corresponding to the fragment $\mathrm{Ni}\left[\left(\mathrm{S}_{2} \mathrm{CSC}_{2} \mathrm{H}_{5}\right)_{2}\right]^{+}$. This indicates, in both cases, the strong chelating property of trithiocarbonates. The various fragments observed are in agreement with the molecular formula of the complexes.

Table 4. Mass fragments of bis(S-ethyltrithiocarbonato)bis(4-cyanopyridine) nickel(II)

\begin{tabular}{ccc}
\hline Mass $m / z$ & Relative abundance & Possible formulae of the fragment \\
\hline 545 & $22 \%$ & $\mathrm{Ni}\left[\left(\mathrm{S}_{2} \mathrm{CSC}_{2} \mathrm{H}_{5}\right)_{2}\left(\mathrm{C}_{6} \mathrm{H}_{4} \mathrm{~N}_{2}\right)_{2}\right]^{+}$. \\
336 & $100 \%$ & $\mathrm{Ni}\left[\left(\mathrm{S}_{2} \mathrm{CSC}_{2} \mathrm{H}_{5}\right)_{2}\right]^{+}$. \\
199 & $35 \%$ & $\mathrm{Ni}\left[\left(\mathrm{S}_{2} \mathrm{CSC}_{2} \mathrm{H}_{5}\right)\right]^{+}$. \\
136 & $58 \%$ & {$\left[\left(\mathrm{~S}_{2} \mathrm{CSC}_{2} \mathrm{H}_{5}\right)\right]^{+}$.} \\
108 & $17 \%$ & {$\left[\left(\mathrm{~S}_{2} \mathrm{CS}\right]^{+}\right.$.} \\
73 & $24 \%$ & {$\left[\mathrm{~S}_{2} \mathrm{C}\right]^{+}$.} \\
\hline
\end{tabular}

On the basis of above mentioned studies, following structure can be assigned to the adducts

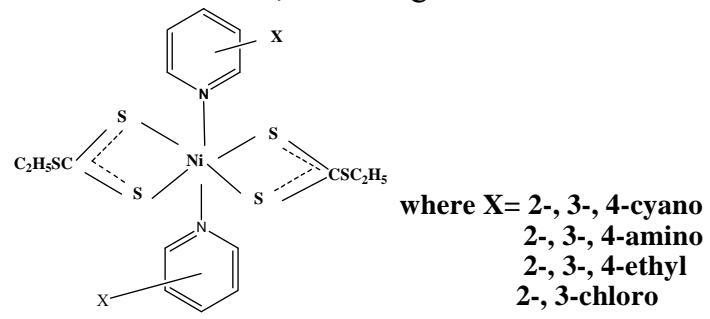




\section{Antifungal activities}

The antifungal activity of some novel investigated 1:2 addition complexes were carried out against two fungal strains 'Fusarium oxysporium and Sclerotium rolfsii' by the poisoned food method using potato Dextrose Agar (PDA) as the nutrient medium ${ }^{26}$. The complexes were dissolved in DMF and were added to potato dextrose agar medium ${ }^{27}$. These were then poured into sterile Petri-dishes and were left to solidify. Using a cork borer $(6 \mathrm{~mm}$ in diameter), the spores of the fungus were suspended on the medium at the centre. Finally the dishes were incubated at $27{ }^{\circ} \mathrm{C}$ for four days. The linear growth of the fungus in controlled manner was recorded at different concentrations of the complexes and a clear inhibition was noticed with all the complexes. Antifungal activities of the addition complexes bis(Sethyltrithiocarbonato) bis(4-ethylpyridine)nickel(II), bis(S-ethyltrithiocarbonato)bis(3chloropyridine)nickel(II) were recorded against Fusarium oxysporium while the antifungal activities of the adducts bis(S-ethyltrithiocarbonato)bis(4-cyanopyridine)nickel(II) and bis(S-ethyltrithiocarbonato)bis(4-aminopyridine)nickel(II) were recorded against Sclerotium rolfsii and are shown in Figure 2. The screening results are summarized in Table 5. The results obtained from these studies suggest that as the concentration of the complex increases the colony diameter decreases and hence the percentage inhibition increases.

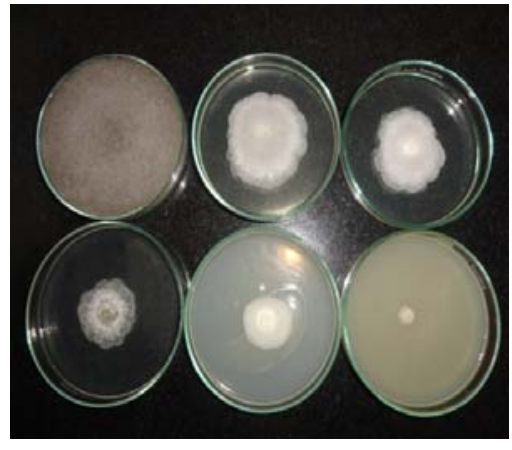

$\operatorname{Bis}(S$-ethyltithiocarbonato)bis(4-ethylpyridine) nickel(II)

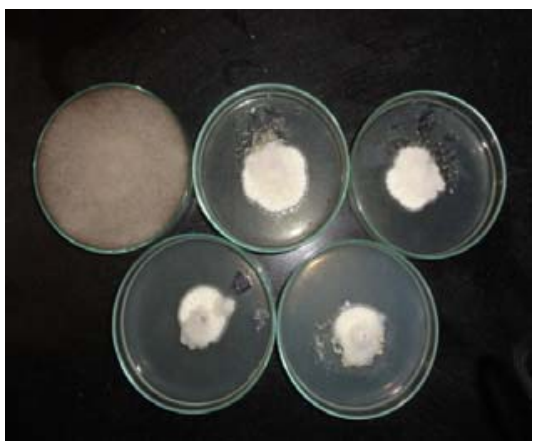

Bis(S-ethyltrthiocarbonato)bis(4-aminopyridine) nickel(II) (a)

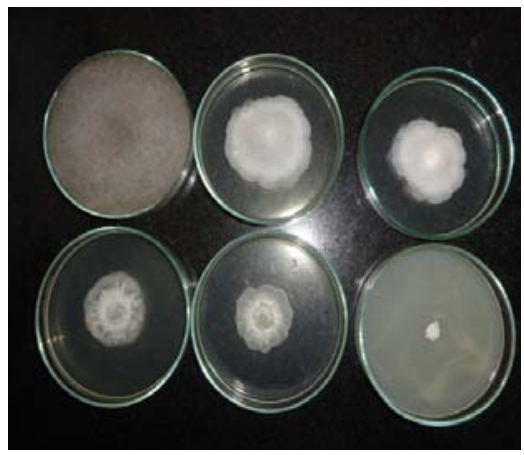

$\operatorname{Bis}(S$--ethyltrithiocarbonato)bis(3-chloropyridine) nickel(II)

(b)

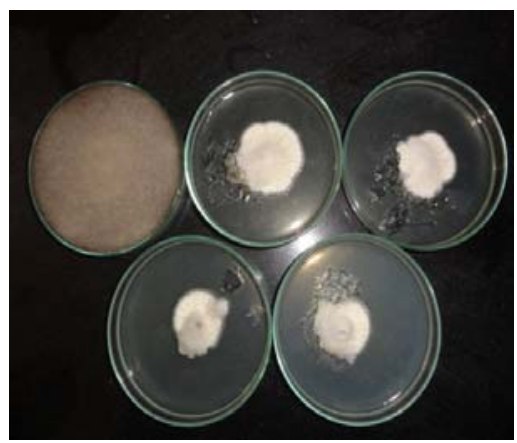

Bis(S-ethyltrithiocarbonato)bis(4-cyanopyridine) nickel(II)

Figure 2. Antifungal activities of some adducts of bis(S-ethyltrithiocarbonato)nickel(II) with nitrogen donor ligands against (a) Fusarium oxosporium and (b) Sclerotium rolfsii 
Table 5. Antifungal activities of some adducts of bis(s-ethyltrithiocarbonato)nickel(ii) with heterocyclic amines against Fusarium oxosporium and Sclerotium rolfsii Colony Diameter in control $=80 \mathrm{~mm}$

\begin{tabular}{|c|c|c|c|c|c|}
\hline $\begin{array}{l}Z_{z} \\
\dot{n}\end{array}$ & Adittion complex & $\begin{array}{c}\text { Colony } \\
\text { Diameter, } \\
\mathrm{mm}\end{array}$ & Concentration & $\begin{array}{c}\text { Colony } \\
\text { diameter, mm }\end{array}$ & $\begin{array}{c}\text { \%Inhibition } \\
\mathrm{I}=[(\mathrm{CT}) / \\
\mathrm{C}] \times 100\end{array}$ \\
\hline \multirow{4}{*}{1} & & \multirow{4}{*}{80} & 50 & 72 & 10.0 \\
\hline & bis(S-ethyltrithiocarbonato) & & 100 & 60.5 & 24.37 \\
\hline & $\begin{array}{l}\text { bis(4-etnylpyridine) } \\
\text { nickel(II) }\end{array}$ & & 150 & 45.1 & 43.62 \\
\hline & & & 200 & 20.2 & 74.75 \\
\hline \multirow{4}{*}{2} & & \multirow{4}{*}{80} & 50 & 88 & 8.88 \\
\hline & bis(S-ethyltrithiocarbonato) & & 100 & 53.5 & 40.55 \\
\hline & nickel(II) & & 150 & 22.9 & 74.58 \\
\hline & & & 200 & 14 & 84.44 \\
\hline \multirow{4}{*}{3} & & \multirow{4}{*}{80} & 50 & 72.8 & 9.0 \\
\hline & bis(4-aminopyridine) & & 100 & 55.5 & 30.6 \\
\hline & nickel(II) & & 150 & 30.0 & 62.5 \\
\hline & & & 200 & 12.6 & 84.25 \\
\hline \multirow{4}{*}{4} & & \multirow{4}{*}{80} & 50 & 78.0 & 2.5 \\
\hline & bis(S-ethyltrithiocarbonato) & & 100 & 62.7 & 21.6 \\
\hline & $\begin{array}{l}\text { bis(4-cyanopyridıne) } \\
\text { nickel(II) }\end{array}$ & & 150 & 40.1 & 49.87 \\
\hline & & & 200 & 20.3 & 74.62 \\
\hline
\end{tabular}

\section{Conclusion}

The adducts of bis(S-ethyltrithiocarbonato)nickel(II) with nitrogen donors are synthesized and on the basis of various physico-chemical techniques and spectroscopic studies are proposed to have distorted octahedral geometry. Some of these are found to be active against fungal strains.

\section{Acknowledgement}

Authors are thankful to Prof. R. K. Bamezai, PG Deptt. of Chemistry, University of Jammu, Jammu for carrying out thermal studies, Indian Institute of Integrative Medicine, Jammu for providing mass spectra and one of the authors, Gurpreet Kour acknowledge UGC-CSIR New Delhi for funding the research.

\section{References}

1. Wasson J R, Woltermann G M and Stoklosa H J, Top Curr Chem., 1973, 35(3-4), 65.

2. Livingstone S E, in Comprehensive Coordination Chemistry (Eds.), Wilkinson G, Gillard R D and McCleverty J A, (Oxford: Pergamon Press), 1987, 2, 633-659.

3. Haiduc I, In Comprehensive Coordination Chemistry- II (Eds.), McCleverty J A and Meyer T J, (Elsevier), 2004, vol 1, Chapter 1.15, 349-376.

4. San H Thang, Chong Y K, Roshan T A Mayadunne, Graeme Moad and Ezio Rizzardo, Tetrahedron Lett., 1999, 40(12), 2435-2438;

DOI:10.1016/S0040-4039(99)00177-X

5. Pastorek R, Travnicek Z, Sindelar Z, Klicka R, Jaromir M and Brezina F, Polyhedron, 1958, 14(12), 1615-1620; DOI:10.1016/0277-5387(94)00433-F 
6. Ballester L, Gutierrez A, Perpinan M F and Caridad Ruiz-Valero, Polyhedron, 1996, 15(7), 1103-1112; DOI:10.1016/0277-5387(95)00358-4

7. Yin H D and Wang C H, Appl Organometal Chem., 2005, 19(3), 400; DOI:10.1002/aoc.859

8. Haiduc I, Semeniuc R F, Campian M, Ch Kravtsov V, Simonov Y A and Lipkowski J, Polyhedron, 2003, 22(21), 2895-2900; DOI:10.1016/S0277-5387(03)00399-1

9. Chouhan H P S, Bakshi A and Bhatia S, Phosphorus Sulfur Silicon, 2011, 186, 345-353; DOI:10.1080/10426507.2010.501320

10. Chaudhari K R, Wadawale A P, Jain V K, Yadav N and Bohra R, Indian J Chem., 2010, 49A, 34-38.

11. Vicente J, Chicote M T, Gonzalez-Herrero P and Jones P G, Inorg Chem., 1997, 36(25), 5735-5739; DOI:10.1021/ic970478c

12. Struck R F and Waud W R, Cancer Chemother Pharmacol., 2006, 57(2), 180-184,

13. Vincete J, Chicote M T, Gonzalez Herrero P and Jones P G, J Chem Soc Chem Commun.. 1995, 7, 745-746; DOI:10.1039/C39950000745

14. Dehmel F, Ciossek T, Maier T, Weinbrenner S, Scmidt B, Zoche M and Beckers T, Bioorg Med Chem Lett., 2007, 17(17), 4746-4752; DOI:10.1016/j.bmcl.2007.06.063

15. Srivastava A, Singh S K and Gupta A, Analyst, 1990, 115(4), 421-423; DOI:10.1039/AN9901500421

16. Ali M F and Abbas S, Fuel Processing Technology, 2006, 87(7), 573-584; DOI:10.1016/j.fuproc.2006.03.001

17. Hyde J, Venkatasubramanian K and Zubieta J, Inorg Chem,, 1978, 17(2), 414-426; DOI:10.1021/ic50180a046

18. Jubert C, Mohamadou A, Marrot J and Barbier J P, J Chem Soc., Dalton Trans., 2001, 8, 1230; DOI:10.1039/B010074I

19. Prasad S and Agarwal R K, Res Lett Inorg Chem., 2008, 350921.

20. Carmona E, Contreras L, Sánchez L J, Puebla E G and Monge A, J Chem Soc., Dalton Trans., 1989, 2003-2009; DOI:10.1039/DT9890002003

21. Perpinan M F, Ballester L, González-Casso M E and Santos A, J Chem Soc., Dalton Trans., 1987, 281-284; DOI:10.1039/DT9870000281

22. Lee C M, Chiou T W, Chen H H, Chiang C Y, Kuo T S and Liaw W F, Inorg Chem., 2007, 46(21), 8913-8923; DOI:10.1021/ic700719h

23. Spek A L, Acta Cryst., 2009, D65, 148-155.

24. Silverstein R M, Bassler G C and Morrill T C, Spectrometric of Organic Compounds, $4^{\text {th }}$ Ed., Willey: New York, 1981, 3-15.

25. Kheiri F M N, Tsipis C A and Manoussakis G E, Inorg Chim Acta, 1977, 25, 223-227; DOI:10.1016/S0020-1693(00)95717-7

26. Parekh H M, Pansuriya P B and Patel M N, Polish J Chem., 2005, 79, 1843-1851.

27. Li W, Yin H, Wen L and Wang D, Acta Crystallogr Sect E., 2009, 65(Pt 1), m 31; DOI:10.1107/S1600536808040804 